\title{
TRAFNOŚĆ I RZETELNOŚĆ TESTU JAKO MIARY JEGO POPRAWNOŚCI, CZYLI O BEECACH W KONSTRUOWANIU JĘZYKOWYCH TESTÓW OSIĄGNIĘĆ
}

Słowa kluczowe: test osiągnięć, funkcja pomiaru dydaktycznego, rzetelność, trafność, czynniki wpływające na trafność/rzetelność testu, błędy konstrukcyjne

Streszczenie. Narzędziem pomiaru najczęściej stosowanym w dydaktyce języka jest test osiągnięć. Za jego pomocą określa się stopień opanowania przez uczących się określonego materiału i/lub wielkość przyrostu ich umiejętności językowych. Błędy popełniane na etapie konstruowania testu osiągnięć w zakresie doboru treści podlegających sprawdzeniu, zadań testowych oraz zastosowanych kryteriów poprawy mogą fałszować rzeczywisty obraz umiejętności zdających, niesłusznie je przeceniając lub dostatecznie ich nie dowartościowując. W niniejszym tekście analizie poddaje się czynniki wpływające na trafność oraz rzetelność testu osiągnięć, które są podstawowymi wyznacznikami jego poprawności.

\section{WSTĘP}

Test językowy najczęściej definiuje się jako procedurę dokonywania ewaluacji określonych aspektów umiejętności językowych, która ma umożliwić uczącym się

wykazanie się wiedzą lub sprawnościami w sposób na tyle zwięzły, aby można było ocenić wyniki i z poziomu wykonania zadań wyciągnąć wnioski o ogólnym poziomie działania językowego, jakiego możemy oczekiwać od nich bądź obecnie, bądź też w przyszłości.

(Ingram 1983, s. 225)

\footnotetext{
${ }^{1}$ aseretny@poczta.onet.pl; Centrum Języka i Kultury Polskiej w Świecie, Wydział Polonistyki, Uniwersytet Jagielloński, ul. Grodzka 64, 31-044 Kraków.

${ }^{2}$ ewa.lipinska@uj.edu.pl; Centrum Języka i Kultury Polskiej w Świecie, Wydział Polonistyki, Uniwersytet Jagielloński, ul. Grodzka 64, 31-044 Kraków.
} 
Narzędziem pomiaru wiedzy i umiejętności uczących się najczęściej stosowanym w dydaktyce języków obcych, w tym także polszczyzny, są testy osiągnięć, nazywane inaczej sprawdzianami (testami) nauczycielskimi. W przeciwieństwie do testów biegłości są one całkowicie zależne od programu kształcenia, a co za tym idzie - oparte na podręczniku (zob. Seretny, Lipińska 2011). Warunkuje to ich dwojaki cel: pierwszym jest określenie, którą część materiału, będącego przedmiotem nauczania w czasie bezpośrednio poprzedzającym pomiar, a ujętego w założonym programie, uczący się już opanowali, drugim - wskazanie stopnia, w jakim treści te zostały przez nich przyswojone.

Dla wielu uczących opracowanie poprawnego testu stanowi niemały problem (zob. Wysocka 2009). Sięgają więc chętnie po gotowe sprawdziany (czasem towarzyszące podręcznikom). Nie jest to jednak rozwiązanie właściwe, gdyż po pierwsze obejmują one wyłącznie materiał zawarty w książce, pomijając inne, omawiane w czasie lekcji treści dydaktyczne, po drugie - udostępnione uczącym się (wraz z odpowiedziami) zostają przekazane kolejnym rocznikom (Dziuba 2000, s. 15-16). Kłóci się to z istotą kontroli wyników, dlatego każdy nauczyciel powinien samodzielnie opracowywać testy osiągnięć, dbając o trafność, rzetelność i praktyczność dokonywanego pomiaru³.

\section{TRAFNOŚĆ I RZETELNOŚĆ NARZĘDZIA POMIARU}

Trafność jest to stopień dokładności, z jaką określone narzędzie (tu: test) mierzy to, co miało mierzyć (Niemierko 1975, s. 169). Najczęściej dzieli się ją na wewnętrzną oraz zewnętrzną. W ramach trafności wewnętrznej bada się, m.in., zgodność:

- treści testu z treściami nauczania - trafność treści (ang. content validity),

- sposobów pojmowania biegłości językowej ze sposobami jej sprawdzaniatrafność teoretyczna (ang. construct validity).

W obrębie trafności zewnętrznej natomiast podejmuje się próby ustalenia, czy i w jakim stopniu test właściwie ocenia umiejętności językowe uczących się $\mathrm{w}$ porównaniu z innymi pomiarami, równoczesnymi (trafność zbieżna, diagnostyczna; ang. concurrent validity) lub przesuniętymi w czasie (trafność prognostyczna; ang. predictive validity).

Rzetelność definiuje się jako jednorodność, stałość wyników. Chodzi zatem o konsekwencję, z jaką test mierzy to, co miał mierzyć (Niemierko 1975, s. 220). $\mathrm{W}$ ustalaniu jej poziomu pomocne są różne metody, np.: retestowa, połówkowa, wersji równoległych, przy czym im mniej rozbieżności pojawia się między ko-

${ }^{3}$ Trafność i rzetelność, jako kwestie merytoryczne, omawiamy szeroko poniżej; o kwestiach praktycznych wspominamy na końcu tekstu. 
lejno uzyskiwanymi wynikami, tym większa wiarygodność stosowanego testu. Uczący się, dwukrotnie rozwiązując test (ten sam lub jego wersję równoległą), powinien więc uzyskać podobny wynik (w przypadku, gdy składał się zadań zamkniętych) ${ }^{4}$ lub zostać oceniony w podobny sposób (gdy jego zadaniem było udzielenie odpowiedzi na zadania otwarte). Rzetelność dotyczy bowiem zarówno stałości wyników testu, jak i stałości oceny ${ }^{5}$. Trzeba pamiętać, że dbałość o rzetelność egzaminu, to także przejaw troski o jego trafność, ponieważ obie te cechy są od siebie zależne.

\section{TEST OSIĄGNIĘĆ - JEGO SPECYFIKA I ZNACZENIE W PROCESIE KSZTALCENIA JEZZYKOWEGO}

Testy osiągnięć stanowią integralną część toku nauczania/uczenia się. Nie należą do grupy egzaminów wysokiej stawki ${ }^{6}$ (ang. high-stakes exams), którymi są wszelkiego rodzaju testy biegłości językowej ${ }^{7}$. Są zawsze ukierunkowane na przeszłość, czyli na okres bezpośrednio poprzedzający kontrolę, przy czym wykorzystuje się je zarówno w celu ewaluacji ksztattującej (bieżącej, odnoszącej się do ostatniego tygodnia, poprzedniej lekcji), jak i sumującej (na zakończenie dłuższego okresu nauki, np. semestru, roku).

Jedną ze specyficznych cech testu osiągnięć jest to, że przygotowuje się go zawsze dla konkretnej grupy uczniów pracujących przez ustalony czas z określoną intensywnością pod kierunkiem nauczyciela, który realizuje konkretny program, korzystając przy tym z materiałów dobranych do potrzeb, dostosowanych do możliwości uczących się. Stąd w klasach/grupach na pozór bardzo podobnych, składających się z uczniów o tym samym języku pierwszym, jednolitych pod względem wieku i stopnia zaawansowania, pomiar może wyglądać nieco inaczej,

\footnotetext{
${ }^{4} \mathrm{~W}$ praktyce, zamiast ponownego testowania uczniów z tego samego materiału w identyczny sposób, stosuje się rozmaite techniki szacowania rzetelności (zob. Niemierko 1999, s. 196-201).

${ }^{5}$ Podstawowe zagadnienia związane z trafnością i rzetelnością testu w przystępny sposób omawia Komorowska (2002, s. 22-29), bardziej szczegółowo ujmują je Niemierko (1975, 1999), Messic (1989), Weir (2005), Kane (2006), Fulcher, Davidson (2007). Tam też znaleźć można informacje dotyczące sposobów badania trafności i rzetelności pomiaru. Pierwsze wymagają zastosowania analiz jakościowych, drugie - opierają się głównie na procedurach ilościowych (najprostsze z nich to określanie stopnia trudności/łatwości poszczególnych zadań za pomocą wskaźników trudności/ latwości i wskazywanie ich mocy różnicującej przy wykorzystaniu, np. metody ,,jednych trzecich” (zob. Pukas-Palimąka, Lipińska 1997; Gałyga 2004).

${ }^{6}$ Od wyników niektórych egzaminów osiągnięć jednak sporo może zależeć, na przykład stopień na świadectwie umożliwiający lub nie promocję do następnej klasy, dyplom szkoły językowej z oceną, która decyduje o przyjęciu do pracy itp.

${ }^{7}$ To np. testy plasujące (zob. Lipińska, Seretny 2010) czy testy biegłości. W przeciwieństwie do testów osiągnięć są sformalizowane i wystandaryzowane, ukierunkowane na teraźniejszość.
} 
przy czym im większe zróżnicowanie uczących się, tym wyraźniejsze mogą być te rozbieżności. W testowaniu osiągnięć sprawą niezwykle istotną jest bowiem waga zagadnień podlegających kontroli, wyrażona w punktach za nie przyznawanych. Ich liczba powinna proporcjonalnie odpowiadać czasowi, jaki przeznaczono na realizację określonych kwestii. Innymi słowy, zadania sprawdzające stopień opanowania treści/umiejętności, na których koncentrowało się nauczanie, powinny być wyżej punktowane niż te ćwiczone w mniejszym zakresie. Owo ukierunkowanie na wiadomego odbiorcę powoduje, że testy osiągnięć są mało uniwersalne, zazwyczaj wręcz jednorazowe o formule często umykającej standaryzacji. Mogą one bowiem mieć bardzo zróżnicowaną objętość, czyli być mniej lub bardziej obszerne (kartkówka vs. egzamin semestralny), sprawdzać stopień opanowania aspektów biegłości językowej selektywnie lub kompleksowo, tzn. koncentrować się na badaniu określonej umiejętności czy sprawności (test z rozumienia ze słuchu, quiz słownikowy) albo kilku z nich (test sprawdzający stopień opanowania sprawności i podsystemów języka); można w nich również stosować otwarte i/lub zamknięte zadania, które zazwyczaj składają się z mniejszych cząstek nazywanych jednostkami testu.

Te [testy], które są oparte na zadaniach zamkniętych, czyli niewymagających od uczącego się sformułowania odpowiedzi (produkcji językowej), są bardziej obiektywne niż te, oparte na zadaniach otwartych, w których uczący się muszą samodzielnie udzielić odpowiedzi.

(Programy nauczania ..., 2011, s. 36)

Testowanie osiągnięć pełni cztery istotne funkcje ${ }^{8}$, mające rudymentarne znaczenie zarówno dla uczących, jak i dla uczniów (zob. tabela 1).

Tabela 1. Funkcje testów osiągnięć

\begin{tabular}{|c|c|c|c|c|}
\hline & DYDAKTYCZNA & $\begin{array}{c}\text { STERUJĄCO- } \\
\text { METODYCZNA }\end{array}$ & DIAGNOSTYCZNA & WYCHOWAWCZA \\
\hline 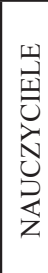 & \multirow{2}{*}{$\begin{array}{l}\text { dowiadują się, w ja- } \\
\text { kim stopniu materiał } \\
\text { językowy został opa- } \\
\text { nowany. }\end{array}$} & $\begin{array}{l}\text { mogą dokonać re- } \\
\text { trospektywnej oceny } \\
\text { przebiegu procesu dy- } \\
\text { daktycznego, wprowa- } \\
\text { dzać zmiany. }\end{array}$ & $\begin{array}{l}\text { mogą określić stopień } \\
\text { przyswojenia materiału } \\
\text { zarówno w odniesie- } \\
\text { niu do całej grupy, jak } \\
\text { też poszczególnych jej } \\
\text { członków. }\end{array}$ & \\
\hline 岁 & & & & $\begin{array}{l}\text { przekonują się, że trze- } \\
\text { ba pracować systema- } \\
\text { tycznie, porządkować } \\
\text { i powtarzać materiał. }\end{array}$ \\
\hline
\end{tabular}

źródło: opracowanie własne

${ }^{8}$ Zob. Komorowska 2002, Seretny, Lipińska 2011. 
Zakres oddziaływania testów osiągnięć na proces kształcenia i jego uczestników (ang. backwash/washback effect) jest więc bardzo szeroki. Nauczycielom pozwalają uzyskać informacje na temat faktycznego stanu wiedzy i umiejętności językowych uczących się, niezbędne do wiarygodnej i bezstronnej ewaluacji ich osiągnięć. Umożliwiają im również ocenę efektywności stosowanych rozwiązań dydaktycznych, wskutek czego mogą, w razie potrzeby, zoptymalizować swoje działania9. Po przeanalizowaniu wyników test „może posłużyć nauczycielowi do takiego zmodyfikowania procesu nauczania, aby uczniowie odnosili możliwie największe korzyści" (Dziuba 2000, s. 16). Poza tym należy pamiętać, że proces ten jest zazwyczaj adresowany do uczniów „średnich”, testy więc pomagają nauczycielowi zauważyć tych, którzy za programem nie nadążają albo jednostki ponadprzeciętne. Uczniom zaś mają pokazać, jak dużo się już nauczyli (a nie udowodnić im, że tej, czy innej rzeczy jeszcze nie wiedzą, nie umieją ${ }^{10}$ ), akcentując mocne strony i pozytywne aspekty uczenia się, unaoczniając im jednocześnie braki i słabsze punkty.

W przypadku uzyskania oceny pozytywnej, uczeń ma poczucie odniesionego sukcesu, co znacząco wpływa na podniesienie jego motywacji do dalszej nauki. Natomiast błędy poprawione w teście pozwalają uczniowi lepiej je sobie uświadomić i unikać ich w przyszłości, co przyspiesza proces uczenia się.

(Dziuba 2000, s. 16)

Testy skłaniają także uczniów do powtarzania przerobionego materiału, co umożliwia im porządkowanie wiedzy, unaocznia zdobyte lub nieopanowane jeszcze umiejętności. Należy więc przekonywać ich o walorach tego typu ewaluacji, szukając sposobów łagodzenia jej negatywnych stron (stres, napięcie, ewentualnie rozczarowanie), przez, na przykład, stwarzanie miłej atmosfery, mobilizowanie do wysiłku, lecz przede wszystkim przez uprzednie informowanie o przebiegu egzaminu, jego zawartości i sposobie oceniania. Nic nie powinno ich zaskoczyć!

Zarówno uczący się, jak i sami nauczyciele nie zawsze w sposób właściwy rozumieją jednak, jak istotne znaczenie w procesie kształcenia ma obiektywne sprawdzanie poziomu osiągnięć. Uczniowie nie dostrzegają w nim odzwierciedlenia swoich umiejętności, lecz stopień, jaki otrzymują/w jakim spełniają określone wymagania. Nie zastanawiają się więc nad tym, czego jeszcze nie umieją. Tymczasem wskazywanie problemów, poszukiwanie źródeł trudności oraz sposobów ich przezwyciężania przyczynia się znacząco do kształtowania u nich postawy autonomicznej (zob. Wilczyńska 1999). Uczący z kolei zbyt często traktują testy osiągnięć wyłącznie jako narzędzie pozwalające na ewaluację postępów swoich

${ }^{9}$ Jeśli jakieś zagadnienie jest w podręczniku słabo lub w nieodpowiednim dla danej grupy wymiarze opracowane (np. jest zbyt mało ćwiczeń), a egzamin pokazuje, że zdający sobie z nim nie poradzili - uczący musi wrócić do tego zagadnienia, posiłkując się innymi pomocami (np. napisać autorskie ćwiczenia, sięgnąć do innych podręczników itp.)

${ }^{10}$ Zob. definicję testu we wprowadzeniu. 
podopiecznych, „podstawę wystawienia oceny”, nie widząc w nich źródła istotnych informacji zwrotnych (ang. feedback) ${ }^{11}$, dzięki którym monitoruje się proces nauczania, zwiększając przy tym jego efektywność. Analiza wyników sprawdzianu może więc i powinna stać się okazją do autorefleksji dla obu stron procesu kształcenia. Dlatego też należy omawiać test i jego wyniki, co stanowi końcowy, choć nie zawsze dający się zastosować ${ }^{12}$, etap kontroli wyników. Przynosi to korzyści nie do przecenienia obydwu stronom.

\section{TRAFNOŚĆ I RZETELNOŚĆ TESTU - JAK JE ZAPEWNIĆ?}

Test osiągnięć, naszym zdaniem, powinna cechować wysoka trafność wewnętrzna oraz rzetelność stałościowa ${ }^{13}$. Musi być także sumiennie punktowany (oceniany). Warto zatem wiedzieć:

- jakie czynniki wpływają na poprawność zastosowanych w nim rozwiązań, skutkujących wyższym lub niższym poziomem trafności;

- jak należy starać się o wiarygodność narzędzia pomiaru i w jaki sposób ją podnosić.

Błędy popełniane przez nauczycieli (np. nieprawidłowy dobór zadań, ich niewłaściwe ukierunkowanie, nieodpowiedni stopień trudności) na etapie planowania i konstruowania testu, mającego na celu badanie osiągnięć uczących się, mogą fałszować rzeczywisty obraz ich umiejętności, niesłusznie je przeceniając lub dostatecznie ich nie dowartościowując.

Formuła testu osiągnięć ze względu na możliwość wykorzystywania go w celu dokonania zarówno ewaluacji kształtującej, jak i sumującej, jest, jak już wspomniano, zróżnicowana. W niniejszym tekście analizie poddane zostaną zagadnienia odnoszące się do nauczycielskich sprawdzianów sumujących ze względu na ich kompleksowy charakter, a także większą rangę, jaką się im przypisuje przy ustalaniu końcowej oceny danego ucznia. Przeprowadza się je na zakończenie kolejnych etapów procesu nauczania, a ewaluacji mogą podlegać wówczas wszystkie elementy kształcenia językowego.

Przygotowanie konkretnych zadań sprawdzających umiejętności uczących się zawsze powinno poprzedzać opracowanie planu testu (specyfikacji), które wiąże się z koniecznością szczegółowej analizy treści określonych w (z)realizowanym programie oraz wytyczonych w nim celów nauczania. Polega ona na

${ }^{11}$ Informacja zwrotna - komentarze osób zaangażowanych w proces testowania (egzaminowanych, egzaminatorów), które stają się podstawą jego ewaluacji (zob. Glosariusz terminów... 2004, s. 76).

${ }^{12} \mathrm{Na}$ przykład w przypadku testu kończącego kurs.

${ }^{13}$ Jest ona także nazywana rzetelnością testu jako zespołu zadań. 
wyodrębnieniu tych zagadnień i umiejętności, które zostaną poddane ewaluacji. Kluczowe znaczenie ma selekcja, rzutująca nie tylko na sposób testowania (dobór technik i ich ukierunkowanie), ale i na rodzaj oraz tematykę materiałów wyjściowych. Będzie też decydująca przy ustalaniu wagi poszczególnych zadań w strukturze określonego komponentu oraz całego testu. Poza ustaleniami merytorycznymi istotne jest również rozstrzygnięcie wielu kwestii technicznych ( Jaka ma być liczba zadań w poszczególnych komponentach? Jak powinny brzmieć instrukcje? Jak będa przeliczane wyniki na oceny?) i logistycznych (Jaki czas potrzebny będzie uczacym się na wypetnienie testu pisemnego? Ile będzie trwat egzamin ustny? Ilu egzaminatorów będzie oceniać test?), gdyż one, w mniejszym lub większym stopniu, też mogą wpływać tak na trafność, jak i rzetelność pomiaru.

Opracowanie szczegółowego planu testu, jego makro- i mikrostruktury, pozwala zatem uniknąć najczęstszych i najpoważniejszych błędów ${ }^{14}$, w czym pomocne mogą być poniższe zestawienia (ang. check lists) ${ }^{15}$. Część z ujętych tabelarycznie zagadnień ma charakter ogólny i dotyczy testu jako całości ( $\mathrm{tj}$. jego makrostruktury) (zob. tabela 2). Większość natomiast odnosi się do rozwiązań szczegółowych, czyli budowy i zawartości poszczególnych komponentów (tj. mikrostruktury testu), sprawdzających stopień opanowania poszczególnych sprawności (RS - rozumienie ze słuchu, RT - rozumienie tekstów, P - pisanie, $\mathrm{M}$ - mówienie) i kompetencji lingwistycznych ( $\mathrm{PG}$ - poprawność gramatyczna, PL - poprawność leksykalna) (zob. tabele 3, 4, 5, 6).

${ }^{14}$ Wyniki, ze względu na czynnik ludzki, zawsze są obciążone pewnymi błędami (zob. Niemierko 1975, 1999). Należy jednak zadbać o to, by usterki testu były jak najmniejsze i nie zniekształcały faktycznego obrazu umiejętności uczących się.

${ }^{15}$ Stanowią one poszerzoną i uzupełnioną wersję spisu zamieszczonego w publikacji Seretny, Lipińska (2011). Listy zagadnień można znaleźć także na stronach internetowych Stowarzyszenia ALTE oraz organizacji EALTA. Dotyczą one jednak testów wysokiej stawki. 


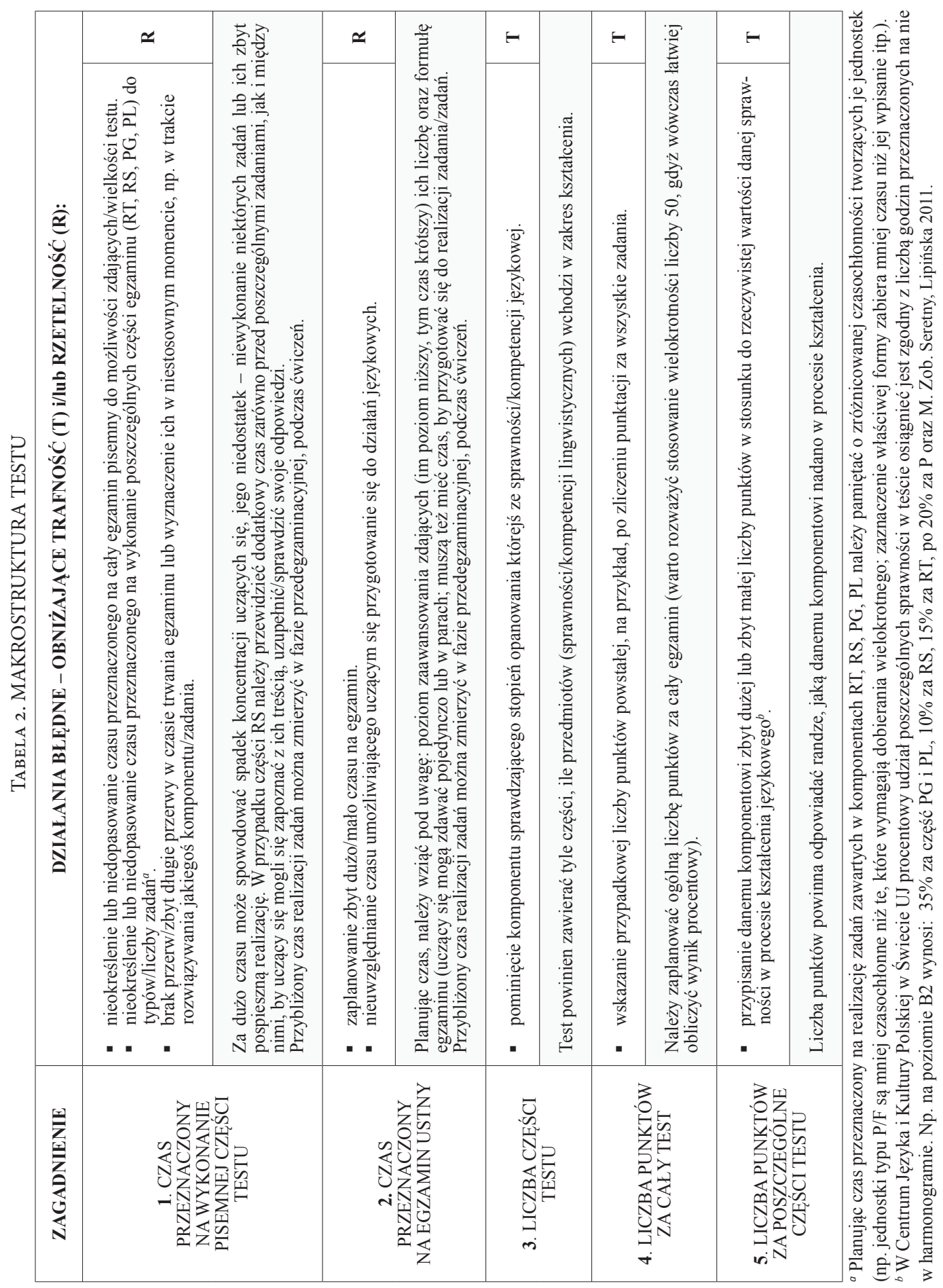




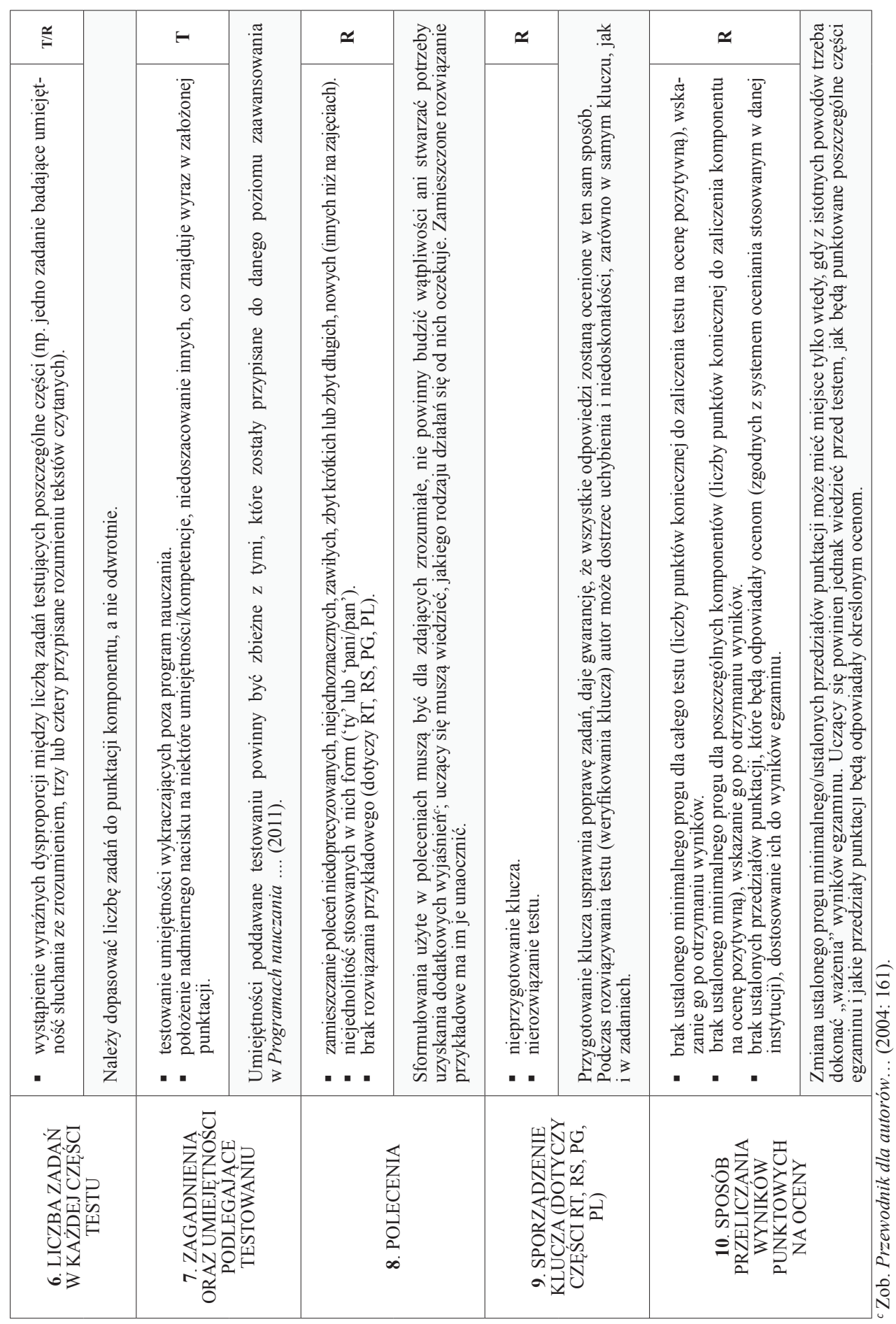




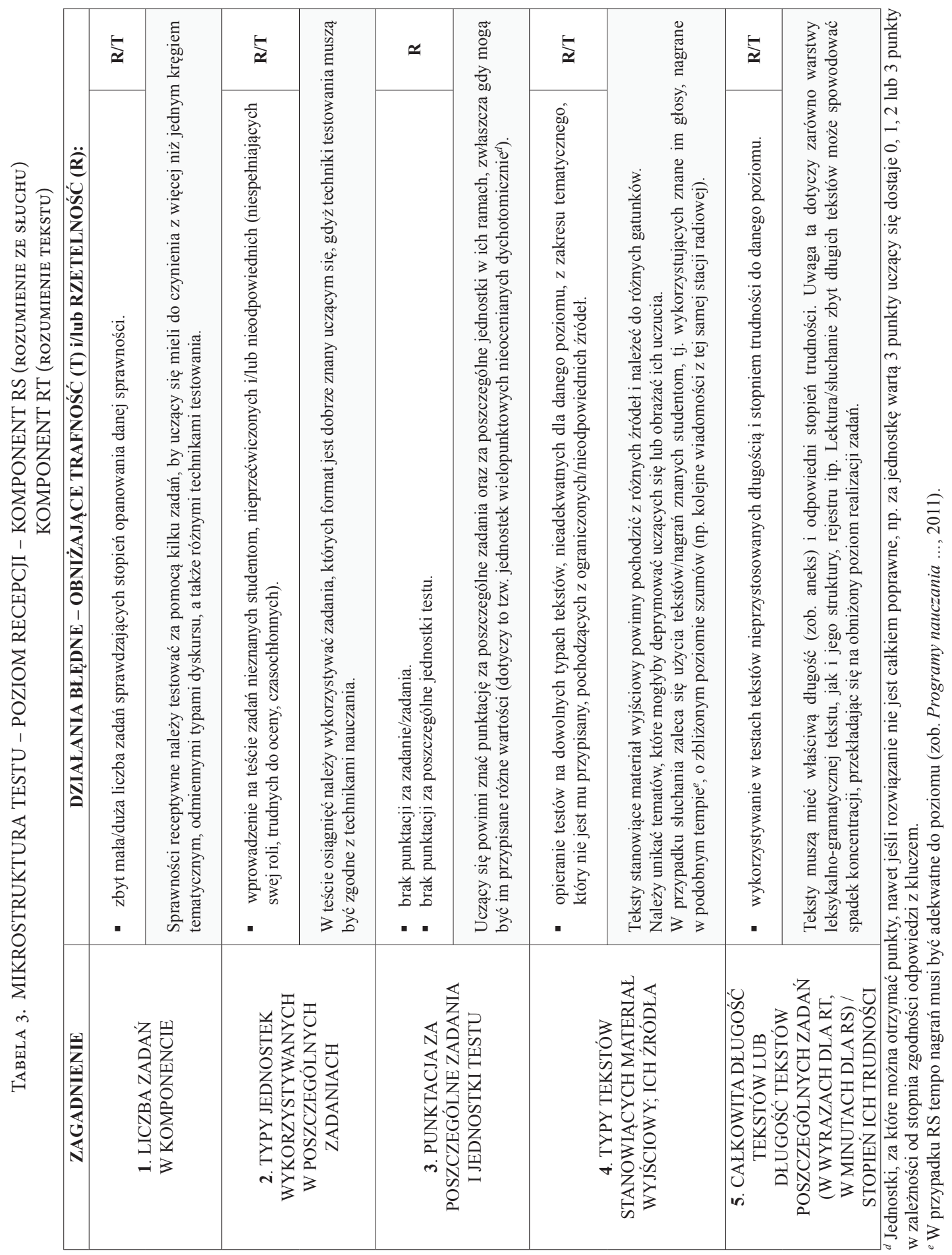




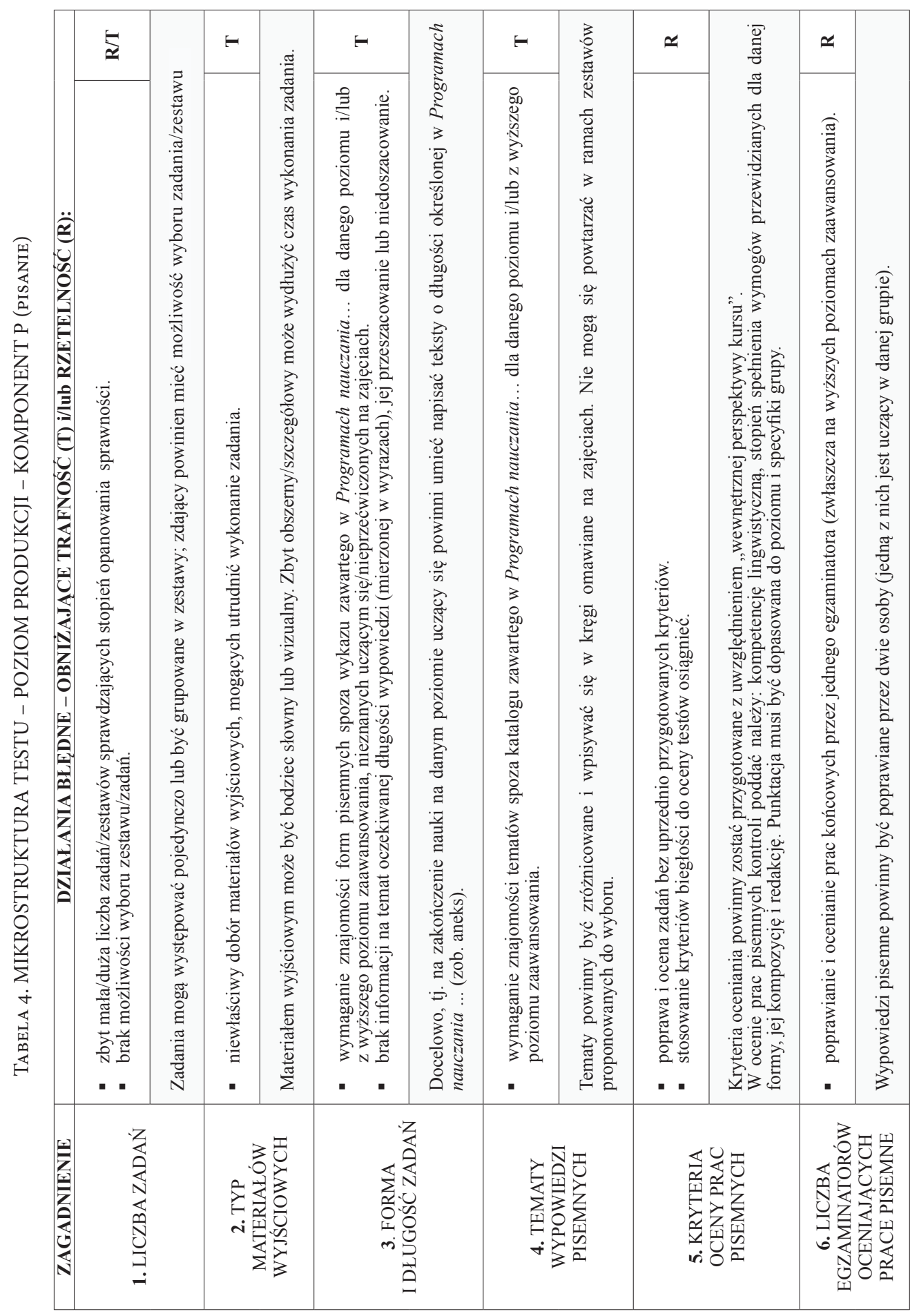




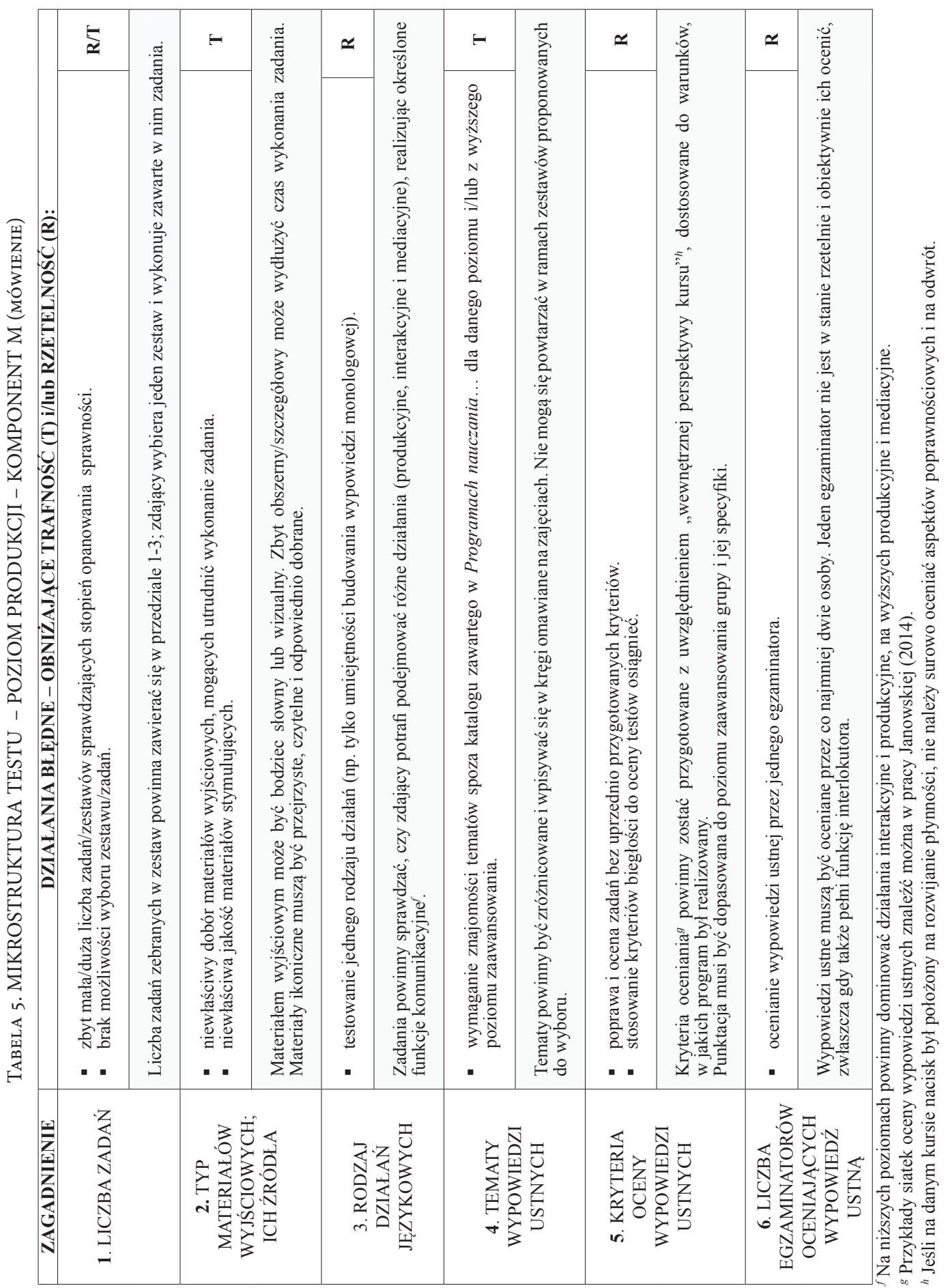




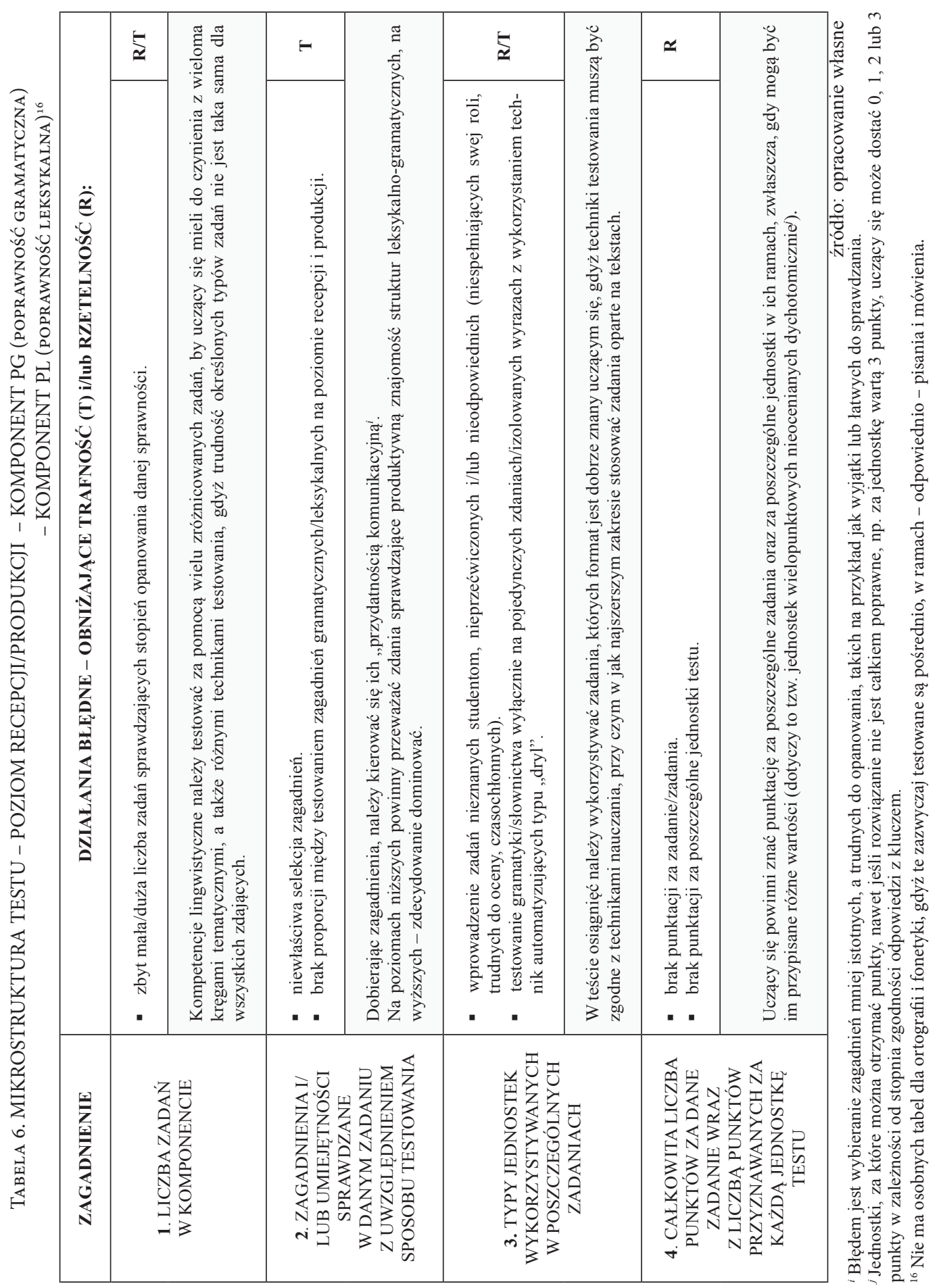




\section{BLĘDY W KONSTRUKCJI ZADAŃ TESTOWYCH}

W niniejszej części zamieszczone zostały przykłady ilustrujące omawiane powyżej zagadnienia. Pochodzą z różnych testów osiągnięć ${ }^{17}$, z części sprawdzających znajomość słownictwa i struktur gramatycznych oraz stopień opanowania sprawności pisania, w których stanowiły całe komponenty (słownictwo B1, pisanie B2) lub ich części (słownictwo A2; gramatyka A1). Wykorzystane w nich rozwiązania nie gwarantują odpowiedniej rzetelności pomiaru, cechuje je również stosunkowo niska trafność, co oznacza, że wyniki uzyskane przez uczących się nie dadzą pełnego obrazu ich faktycznych umiejętności językowych.

${ }^{17}$ Zadania sprawdzające znajomość słownictwa i gramatyki zostały wzięte z prac studentek II roku magisterskich studiów uzupełniających Nauczenie języka polskiego jako obcego w UJ. Autorskie przykłady zestawów do pisania pochodzą z warsztatów dla zespołu autorów zadań opracowujących testy certyfikatowe z języka polskiego jako obcego oraz z prac słuchaczy podyplomowych studiów Nauczanie języka polskiego jako obcego w UJ. Do niektórych przykładów usterki zostały wprowadzone celowo. 

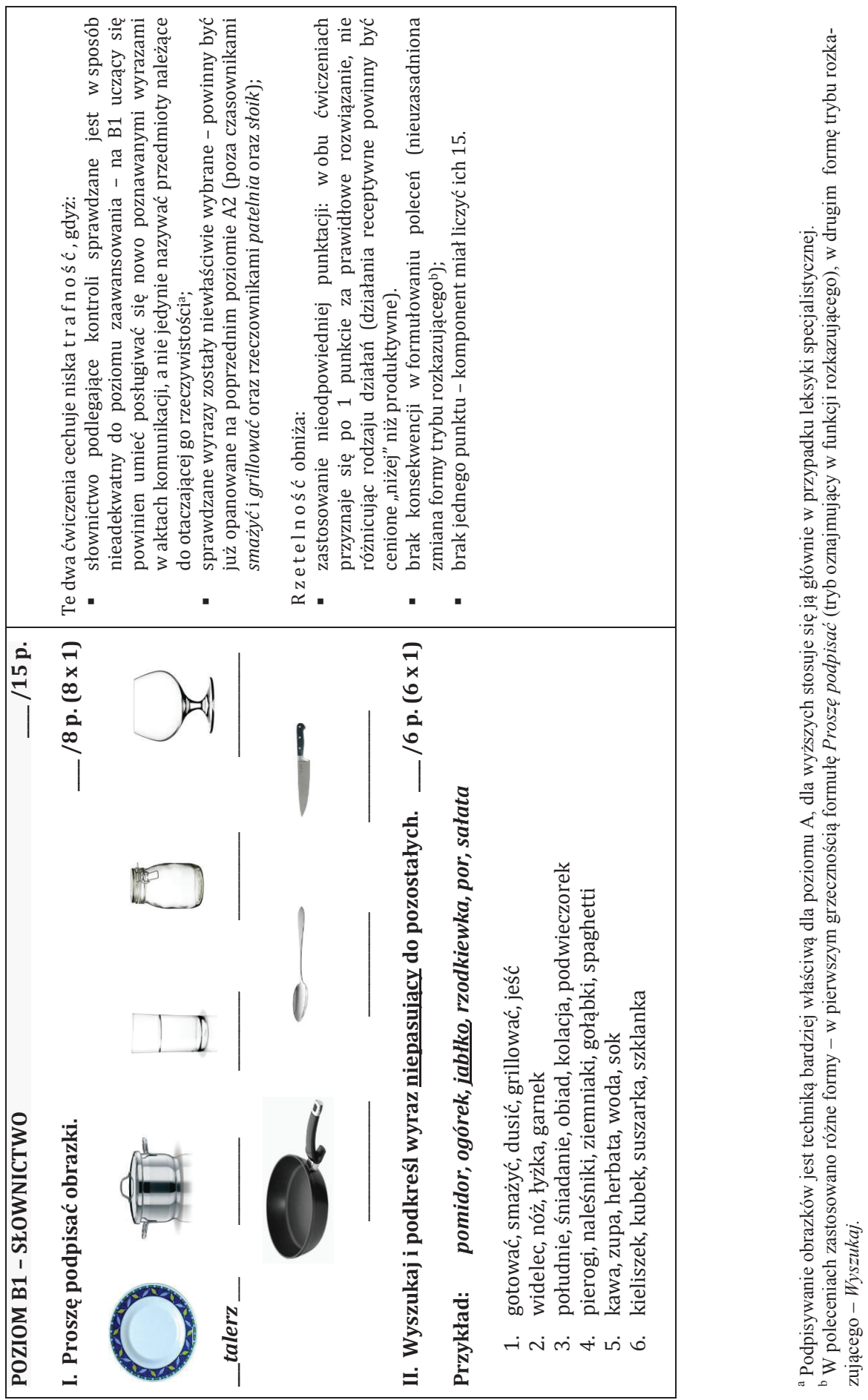

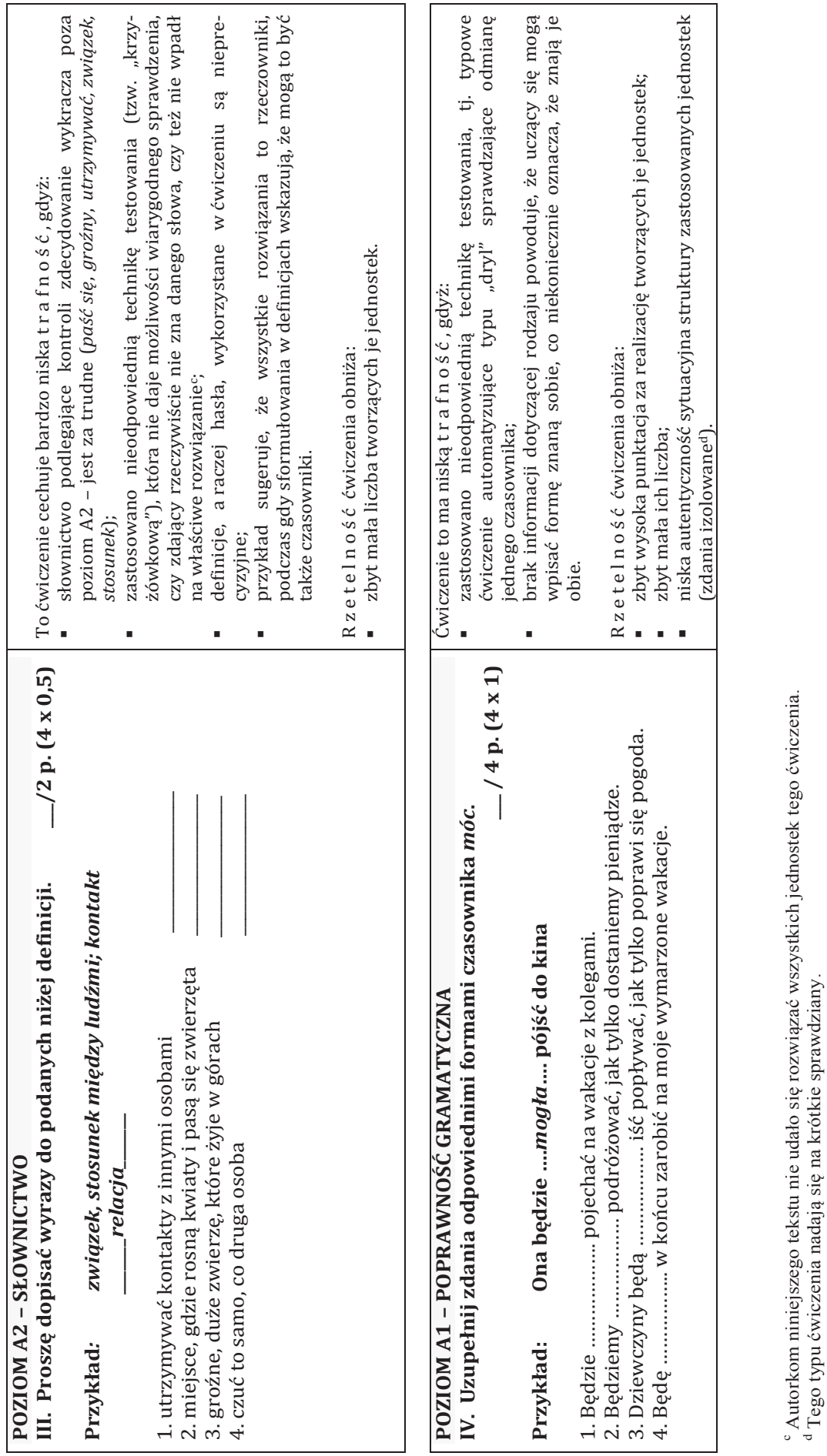


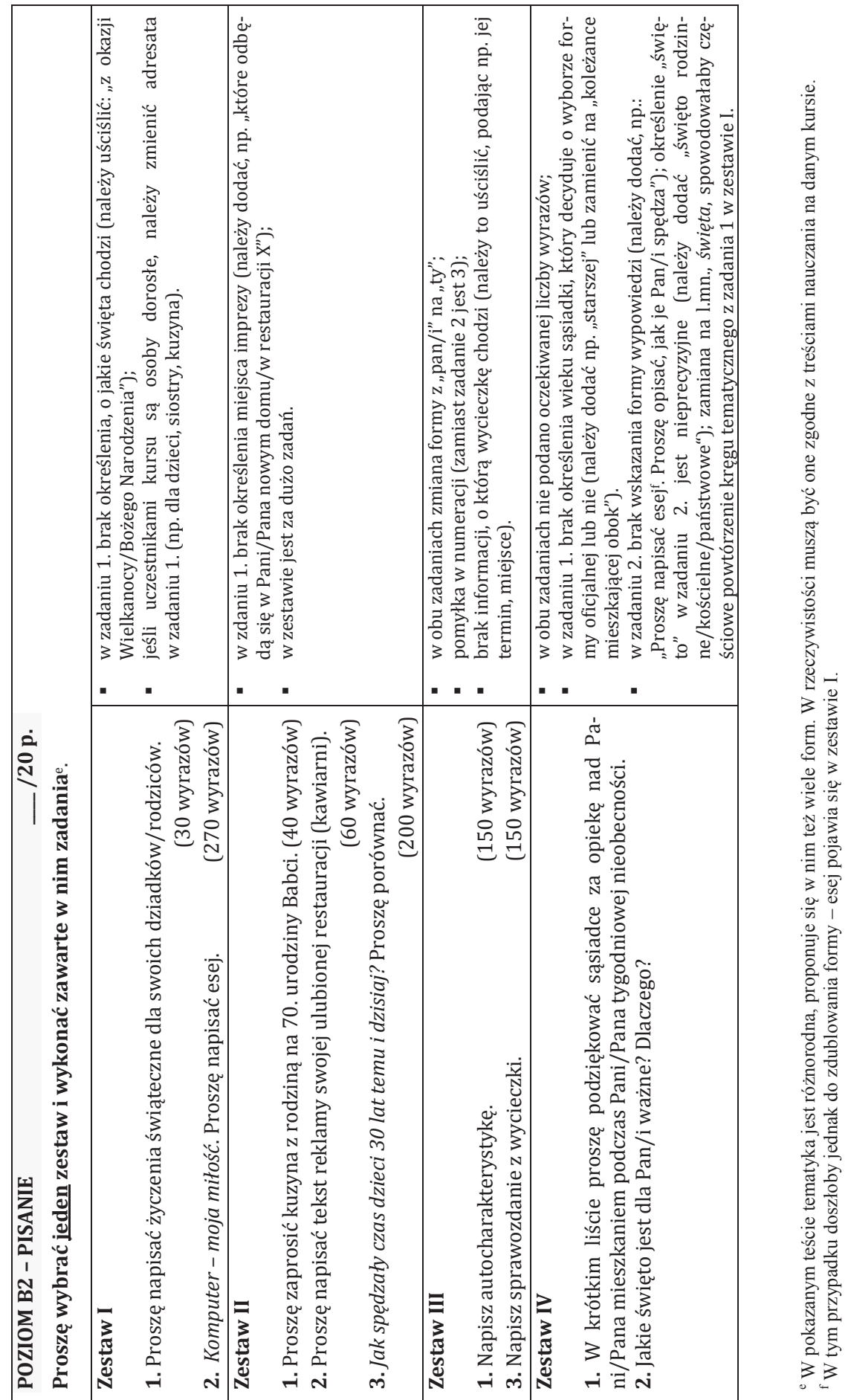




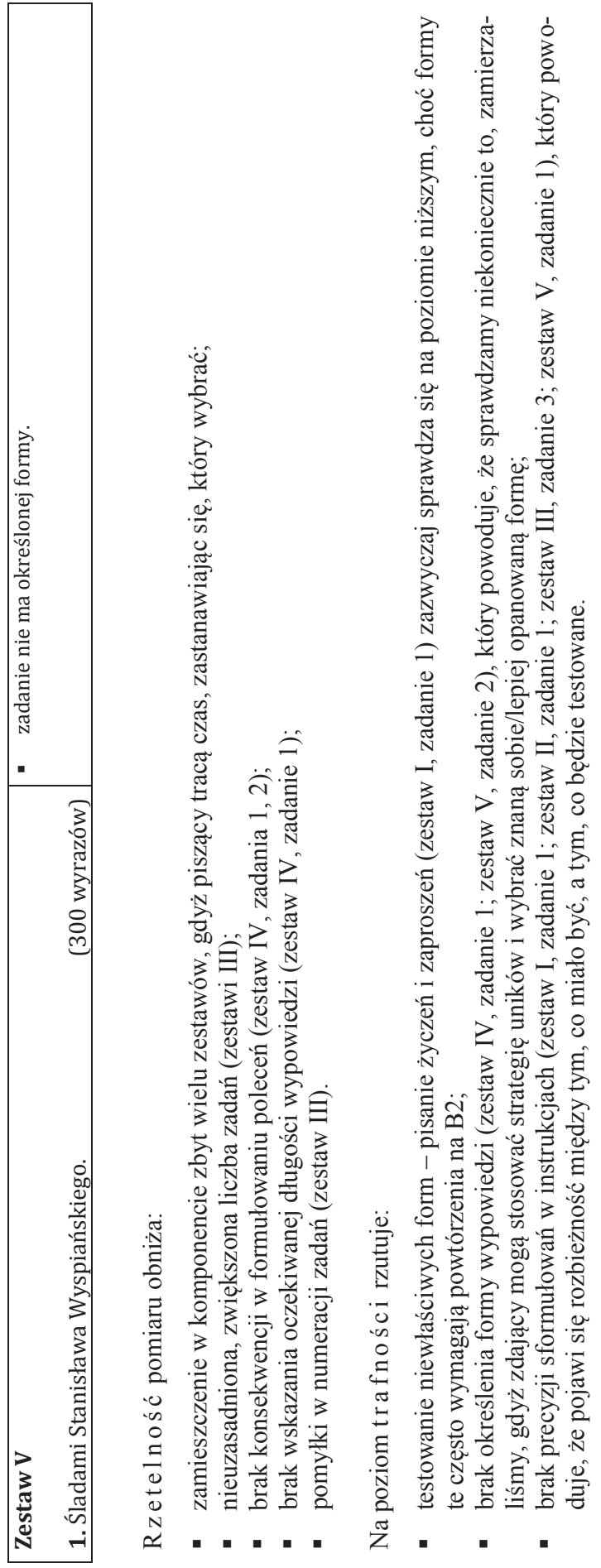




\section{PODSUMOWANIE}

Przygotowanie trafnego i rzetelnego testu osiągnięć sprawdzającego faktyczne umiejętności językowe uczących się wymaga precyzyjnych i przemyślanych działań oraz wiedzy merytorycznej. Przy jego opracowaniu trzeba także pamiętać o kwestiach natury praktycznej, m.in.:

- test musi spełniać określone wymagania techniczne, tj. być przejrzysty, czytelny (kserokopie muszą być dobrej jakości);

- test powinien mieć wyraźnie wydzielone części, wyróżnione polecenia i zaznaczoną punktację;

- miejsca przeznaczone na odpowiedzi uczących się muszą mieć odpowiednią wielkość ${ }^{18}$;

- w teście należy ograniczać liczbę zadań, których przygotowanie jest kosztowne (np. wymagają zastosowania kolorowych kserokopii) lub zbyt czasochłonne (np. wymagają klejenia nagrań, programów tv, przekazów Internetowych itp. $)^{19}$.

Gotowy sprawdzian należy poddać analizie pod kątem autentyczności i interakcyjności wykorzystanych w nim zadań. Przez autentyczność rozumie się stopień, w jakim działania podejmowane przez uczących się w celu realizacji zadań egzaminacyjnych, przypominają te, które mogliby wykonywać w rzeczywistości; interakcyjność natomiast odnosi się do poziomu zaangażowania intelektualnego i emocjonalnego towarzyszącego zdającym w czasie realizacji zadań - im bliższy naturalnemu, tym lepiej (Bachman, Palmer 1996, s. 23-25). Warto go też skonsultować z kolegami/współpracownikami mogącymi dostrzec błędy, które umknęły autorowi, „wnieść uwagi dotyczące konstrukcji, czy podsunąć lepsze rozwiązania" (Dziuba 2000, s. 22). W czasie przeprowadzania testu wskazane jest notowanie wszelkich spostrzeżeń pomocnych przy układaniu kolejnego (np. czas realizacji określonych zadań; czas, w jakim pierwszy/ostatni uczeń oddał pracę pisemną itp.). Bardzo ważna jest również, jak już wspomniano, analiza uzyskanych wyników. Jeśli bowiem test został rozwiązany przez wszystkich na ocenę bardzo dobrą, musiał składać się z zadań zbyt łatwych. Gdy zaś większość radziła z nim sobie z wyraźnymi problemami - tworzące go zadania cechował za wysoki poziom trudności, przy czym w obu przypadkach rezultaty nie pozwalają właściwie różnicować ocen przyznawanych zdającym ${ }^{20}$.

${ }^{18} \mathrm{~W}$ przypadku zadania z jednostkami typu „uzupełnianie luk” wklejanie skopiowanego tekstu z zamalowanymi wyrazami jest przejawem braku profesjonalizmu.

${ }^{19}$ Gdy jednak są one niezbędne, należy rozważyć takie przygotowanie testu/jego fragmentów, by można było go/ich użyć ponownie. Wiąże się to wówczas z koniecznością przygotowania oddzielnych arkuszy odpowiedzi, na których uczniowie będą rozwiązywać zadania.

${ }^{20}$ Należy jednak pamiętać, że rozkładu normalnego, tzw. krzywej Gaussa (zob. Przewodnik dla autorów zadań do testów językowych, 2004) oczekiwać można jedynie w przypadku, gdy grupa piszących jest większa niż 30 osób. W grupach mniej licznych wyniki bywają bardziej spłaszczone, lecz na pewno nie powinny być jednorodne. 
Na zakończenie warto raz jeszcze podkreślić, że test osiągnięć jest bardzo ważnym narzędziem dydaktycznym. Jego tworzeniu powinna więc zawsze towarzyszyć refleksja nad celowością stosowanych rozwiązań oraz ich możliwymi konsekwencjami.

\section{BIBLIOGRAFIA}

Bachman L., Palmer A., 1996, Language Testing in Practice, Oxford.

Dziuba D., 2000, Testy w nauczaniu języków obcych, „Języki Obce w Szkole”, nr 4, s. 15-22.

Fulcher G., Davidson F., 2007, Language Testing and Assessment: An Advanced Resource Book, London-New York.

Gałyga D., 2004, Rzetelność i trafność pomiaru dydaktycznego na wybranych przyktadach testów, w: W. Martyniuk, E. Lipińska, A. Seretny (red.), Opisywanie, rozwijanie i testowanie znajomości języka polskiego jako obcego, Kraków, s. 79-87.

Glosariusz terminów z zakresu testowania biegłości językowej, 2004, Kraków.

Ingram E., 1983, Testy językowe, w: J. B. P. Allen, S. Pit Corder, A. Davies (red.), Kurs edynburski językoznawstwa stosowanego, t. II. Warszawa, s. 225-251.

Janowska I., 2014, Jak oceniać ustne działania językowe uczacych się? Ewaluacja wypowiedzi ustnej w podejściu ukierunkowanym na działanie, w: A. Mielczarek, A. Roter-Bourkane, M. Zduniak-Wiktorowicz (red.), Sukcesy, problemy $i$ wyzwania w nauczaniu języka polskiego jako obcego, Poznań, s. 227-238.

Kane M., 2006, Validation, w: R. L. Brennan (red.), Educational Measurement: Fourth Edition, Westport, CT, s. 17-64.

Komorowska H., 2002, Sprawdzanie umiejętności w nauce języka obcego. Kontrola - ocena - testowanie, Warszawa.

Lipińska E., Seretny A., 2010, Testy plasujace jako narzędzie pomiaru dydaktycznego na przykładzie języka polskiego jako obcego - ocena dotychczasowych doświadczeń, „Neofilolog” nr 34, s. 229-242.

Messick S., 1989, Validity, w: R. L. Linn (red.), Educational Measurement: Third Edition, New York, s. 13-103.

Niemierko B., 1975, Testy osiagnięć szkolnych. Podstawowe pojęcia i techniki obliczeniowe, Warszawa.

Niemierko B., 1999, Pomiar wyników ksztatcenia, Warszawa.

Programy nauczania języka polskiego jako obcego. Poziomy A1-C2, 2011, Kraków.

Przewodnik dla autorów zadań do testów językowych, thum i adaptacja M. Gaszyńska-Magiera i A Seretny, Universitas, Kraków 2004.

Pukas-Palimąka D., Lipińska E. (1997), Ewaluacja testów biegłości do nauczania języka polskiego jako obcego, „Przegląd Polonijny”, z. 2, s. 115-122

Seretny A., Lipińska E., 2011, Kontrola bieżaca (formative evaluation) a kontrola globalna (summative evaluation) - testy osiagnięć w procesie dydaktycznym, w: U. Pluskota, K. Taczyńska (red.), Nowe perspektywy w nauczaniu języka polskiego jako obcego II, Toruń, s. 53-70.

Weir C. J., 2005, Language Testing and Validation. An Evidence-Based Approach, Basingstoke.

Wilczyńska W., 1999, Uczyć się czy być nauczanym? O autonomii w przyswajaniu języka obcego, Warszawa.

Wysocka M., 2009, Badania innowacyjne (action research) jako czynnik stymulujący pracę twórcza nauczycieli języków obcych, w: M. Pawlak, A. Mystkowska-Wiertlak, A. Pietrzykowska (red.), Nauczyciel języków obcych dziś i jutro, Poznań-Kalisz, s. 509-517. 
ANEKS $^{21}$

1.

Długość tekstów stanowiących podstawę wykonania zadań z RS i RT powinna mieścić się w poniższych zakresach (+/- 10\%):

1. dla poziomu A1: 80 - 100 wyrazów

4. dla poziomu B2: $\mathbf{2 5 0}$ - $\mathbf{3 0 0}$ wyrazów

2. dla poziomu A2: $\mathbf{1 2 0}$ - $\mathbf{1 5 0}$ wyrazów

5. dla poziomu $\mathrm{C} 1: \mathbf{3 5 0}$ - $\mathbf{3 5 0}$ wyrazów

3. dla poziomu B1: 200 - 250 wyrazów

6. dla poziomu C2: $\mathbf{3 0 0}$ - $\mathbf{4 0 0}$ wyrazów

2.

Długość wypowiedzi pisemnych uczących się powinna mieścić się $\mathrm{w}$ poniższych zakresach $(+/-10 \%)$ :
1. dla poziomu A1: 100 wyrazów
4. dla poziomu B2: $\mathbf{3 0 0}$ wyrazów
2. dla poziomu A2: 150 wyrazów
5. dla poziomu $\mathrm{C} 1: \mathbf{4 0 0}$ wyrazów
3. dla poziomu B1: 200 wyrazów
6. dla poziomu C2: $\mathbf{5 0 0}$ wyrazów

Anna Seretny, Ewa Lipińska

\section{FACTORS AFFECTING VALIDITY AND RELIABILITY OF ACHIEVEMENT TESTS}

Keywords: achievement test, reliability, validity, test planning, mistakes of the planning phase, factors affecting test reliability and validity, factor analysis

Summary. A language achievement test is the most commonly used evaluation tool in the field of language learning/ teaching. Such tests measure students' mastery of a particular instructional domain in order to make decisions regarding their advancement and/or competency. A well-constructed test will give both the teacher and the students an appraisal of their respective achievements. Administering tests will lose its importance if the items do not pose a particular challenge to the students and/or if they do not adequately reflect the given body of content. The text presents a thorough analysis of the factors affecting validity and reliability of achievement tests. Validity is the most important quality of test use, which concerns the extent to which meaningful inferences can be drawn from test scores. No test can achieve its intended purpose if its results are unreliable.

${ }^{21}$ Dane pochodzą z Programów nauczania... (2011): A1 - s. 36; A2 - s. 67, B1 - 101, B2 - s. 136, C1 - s. 173, C2 - s. 209. 